\title{
C
}

\section{British Ecological Society}

A Draft Scheme for the Representation of British Vegetation in Black and White Author(s): E. J. Salisbury

Source: Journal of Ecology, Vol. 8, No. 1 (Mar., 1920), pp. 60-61

Published by: British Ecological Society

Stable URL: http://www.jstor.org/stable/2255214

Accessed: 03/02/2015 01:49

Your use of the JSTOR archive indicates your acceptance of the Terms \& Conditions of Use, available at http://www.jstor.org/page/info/about/policies/terms.jsp

JSTOR is a not-for-profit service that helps scholars, researchers, and students discover, use, and build upon a wide range of content in a trusted digital archive. We use information technology and tools to increase productivity and facilitate new forms of scholarship. For more information about JSTOR, please contact support@jstor.org.

British Ecological Society is collaborating with JSTOR to digitize, preserve and extend access to Journal of Ecology. 


\section{A DRAFT SCHEME FOR THE REPRESENTATION OF BRITISH VEGETATION IN BLACK AND WHITE}

Black and white representation of Vegetation, always essential for small charts, has become important owing to the prohibitive cost of colour-printing. It is obviously very desirable that the methods of representation should be uniform and standardised. The subject was brought before the Council of the B. E. S. in 1918, and it was then suggested by the present writer that a uniform basis symbol should be employed for each great vegetation type whilst additional symbols should serve to distinguish the different associations. This principle appears to have met with general acceptance, and a sub-committee, consisting of A. G. Tansley, George Morris and the writer, was appointed to formulate a scheme on these lines.

Two alternative schemes were prepared, the one based almost entirely on the use of arbitrary symbols, the other on the use of symbols suggestive of the dominant species. These two schemes were submitted to various ecologists and the sub-committee are indebted to all who have made criticisms or suggestions. In particular they are indebted to Mr T. G. Hill, Prof. F. W. Oliver, Dr W. G. Smith and Prof. R. H. Yapp.

The scheme appended is an attempt to embody the salient features of the two preliminary schemes and to reconcile the diverse views expressed, whilst adopting as far as possible the many valuable suggestions received. It must however be emphasised that it is merely tentative and in no sense final, but is put forward in the hope that all working ecologists will subject it to the test of actual use so that, in the light of the experience thus gained, it may be possible before long to adopt a standard for use in all future publications.

As regards the scale, it is suggested that this should be magnified in accordance with the scale of the map. In general only basis symbols should be employed for scales of one mile to the inch or under. For communities with co-dominants the symbols for these can be intermingled (e.g. mixed Oakwood) whilst the introduction of letters serves to distinguish different dominant species (e.g. Junceta). For the totally submerged types the symbols are placed between the lines. In the case of the maritime basis symbol alone, it is suggested that the general direction should follow the coast line. The demarcation between associations should be indicated by heavy black lines.

Where feasible the symbols of dominants commonly used on the Continent have been adopted (e.g. Fagus, Taxus, Corylus); they are in every case simple in character and make but the slightest demands on draughtsmanship.

For special purposes considerable elaboration will be needed, involving the use of numerous additional symbols, but once a fixed scheme has been adopted such additions should receive the official sanction of the B. E. S. and supplements embodying them would be issued and circulated from time to time. The time has come when it is essential that uniformity should be attained and this will be more difficult the longer the delay.

Criticisms and suggestions are invited.

E. J. SAlisbury. 


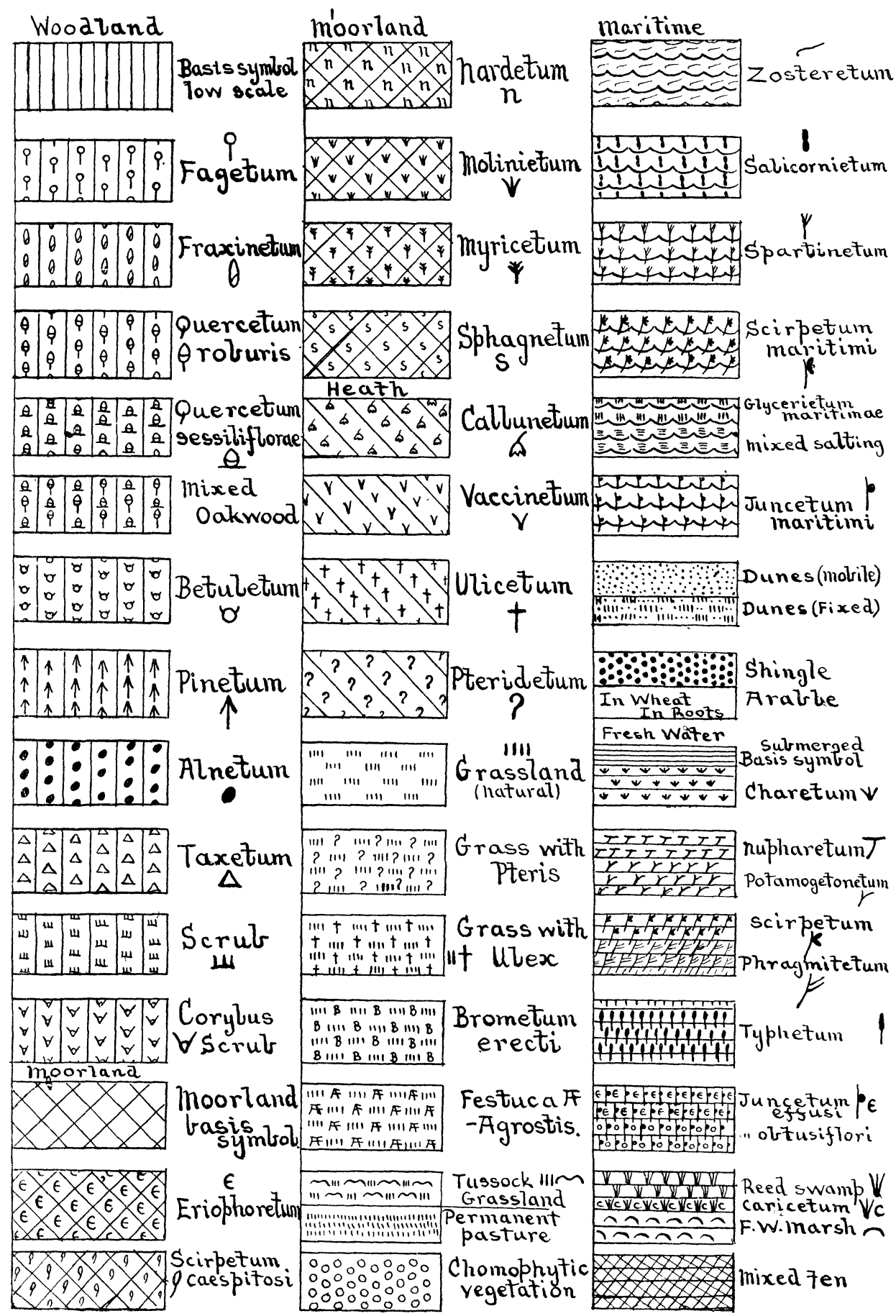

